\title{
Unexpected Significantly Reduced FDG Uptake in the Cerebrum Compared Against Normal Liver Uptake in a Dying Patient
}

\author{
Ölmekte Bir Hastada Normal Karaciğer Uptake'ine Karşın Serebrumda \\ Beklenmeyen Belirgin Düşük FDG Tutulumu
}

Luke I. Sonoda, Bal Sanghera, Gill Vivian, Wai Lup Wong

Mount Vernon Hospital, Paul Strickland Scanner Centre, Middlesex, United Kingdom

\begin{abstract}
F-18 FDG PET-CT scanning plays an important role in the management of fever of unknown origin (FUO). Some elderly patients with FUO can be in their terminal stage of life. An elderly woman was referred for a PET-CT scan to find the etiology of FUO. The scan was inconclusive but showed significantly reduced FDG uptake in the brain and heart, despite normal physiological uptake in the liver and bowel. The patient deceased within the hour post scan. Contrary to common belief, we have shown that cerebral glucose metabolism via cerebral perfusion may be compromised before hepatic and bowel perfusion in a dying patient. (MIRT 2012;21:88-90)

Key words: Fluorodeoxyglucose F18, glucose metabolism disorders, brain vascular disorders, liver, cardiac muscle, physiological processes, fever of unknown origin
\end{abstract}

\section{Özet}

F-18 FDG PET-BT taraması nedeni bilinmeyen ateşin (NBA) yönlendirmesinde önemli bir rol oynar. NBA olan bazı yaşlı hastalar yaşamlarının son evresinde olabilir. Yaşlı bir kadın NBA etiyolojinin araştırılması amacıyla PET-BT tarama için gönderildi. Tarama kesin bir sonuç vermedi ancak karaciğer ve bağırsakta normal fizyolojik uptake'e rağmen, beyin ve kalpte ciddi olarak azalmış FDG uptake'ini gösterdi. Hasta tarama sonrasında bir saat içinde hayatını kaybetti. Yaygın inanışın aksine, ölmekte olan bir hastada serebral perfüzyon yoluyla serebral glukoz metabolizmasının hepatik ve bağırsak perfüzyonundan önce bozulabileceğini gösterdik. (MIRT 2012,21:88-90)

Anahtar kelimeler: Fluorodeoksiglukoz F18, glukoz metabolizması bozuklukları, beyinin damarsal bozuklukları, karaciğer, kardiyak kas, fizyolojik süreçler, sebebi bilinmeyen ateş

\section{Introduction}

Although F-18 FDG PET-CT scanning has now become widely available as a new radiological and nuclear medicine investigation, it is by large considered as a tool of non-acute clinical management such as oncology staging (1), monitoring response to therapies (2), detection of disease recurrence (3) and detection of unknown primary malignancies (4) or infection/inflammation (5). Hence, it is quite unusual to encounter a PET-CT scan of a patient who slowly deteriorated to pass away within 45 minutes after the scan. Unexpectedly we performed a PET-CT scan of a dying patient that demonstrated some unexpected cerebral FDG uptake pattern compared to other remaining organs such as heart, liver and gastrointestinal tract.

\section{Case Report}

A 70 year-old female, with a reduced level of consciousness but who was stable and capable to talk slowly

Address for Correspondence: Luke I. Sonoda MD, Mount Vernon Hospital, Paul Strickland Scanner Centre, Middlesex, United Kingdom Phone: +44 (0) 1923844751 E-mail: luke@sonoda.co.uk

Received: 06.11.2011 Accepted: 12.12.2011 
and communicate at the time of investigation, was referred for a F-18 FDG-PET-CT scan to investigate FUO $(6,7,8)$. The PET$C T$ scan demonstrated moderate subcutaneous oedema (Figure $1 \mathrm{~A}, \mathrm{~B}$ and $\mathrm{C}$ ) and moderate right pleural effusion (Figure $1 \mathrm{~F}$ and $\mathrm{G}$ ) due to fluid overload, but no cause of FUO was identified.

Reduced cardiac FDG uptake (SUV max=1.55, SUV mean $=0.95$ ) was considered as a result of 'fasting' (9), with no feeding for 6 hours prior to the scan (Figure $1 \mathrm{G}$ ). The serum glucose level was $5.6 \mathrm{mmol} / \mathrm{l}$.

The patient had no relevant past medical history and was not on any medication. In particular, the patient did not suffer from any forms of dementia nor pathology involving cerebrum such as Creutzfeldt-Jakobs disease. Physical examinations and routine blood tests were all normal and previous imaging investigations including $\mathrm{CT}, \mathrm{MRI}$ and abdominal ultrasound did not find significant abnormalities.

Diffusely decreased cerebral and cerebellar FDG uptake (SUV max=2.47, SUV mean=1.94) was an unexpected finding (Figure $1 \mathrm{D}$ and $\mathrm{E}$ ), especially because hepatic FDG uptake and intestinal FDG uptake appeared normal (Figure $1 \mathrm{H}$ and I) (10).

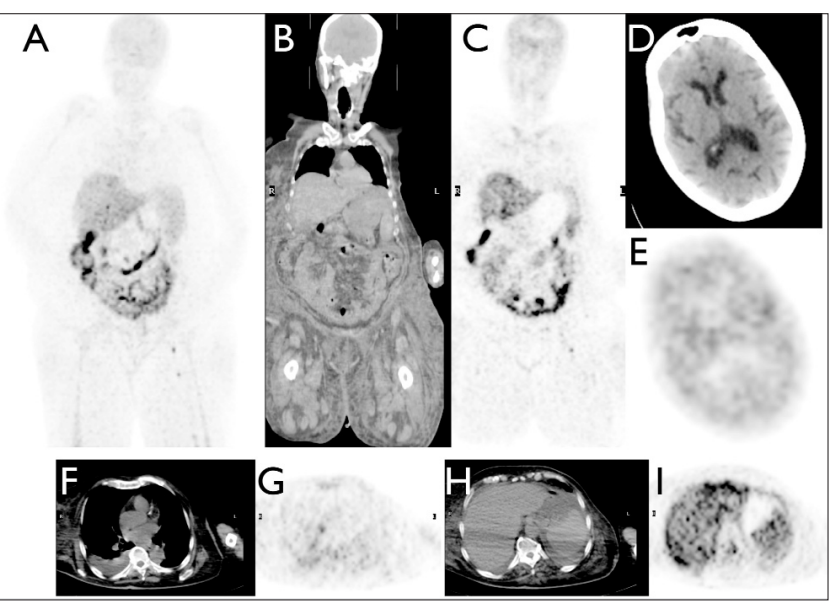

Figure 1. FDG PET-CT scan of the patient. A: MIP PET, B and C: coronal $C T$ and PET, D and E: axial CT and PET at the level of the brain, $F$ and $\mathrm{G}$ : axial $\mathrm{CT}$ and PET at the level of the heart, $\mathrm{H}$ and $\mathrm{I}$ : axial $\mathrm{CT}$ and PET at the level of the liver

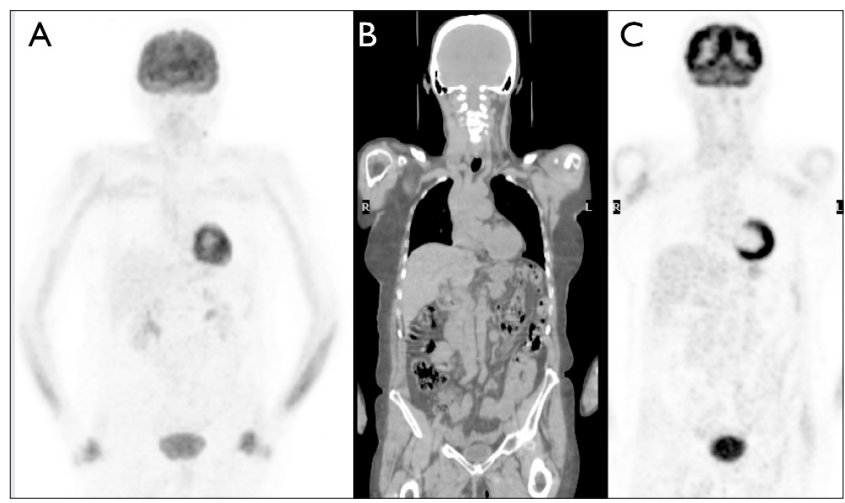

Figure 2. Example of a normal FDG PET-CT scan. A: MIP PET, B and $\mathrm{C}$ : coronal $\mathrm{CT}$ and PET
The patient deteriorated unexpectedly and was deceased 45 minutes after the scan despite attempts of resuscitation. Autopsy did not reveal significant pathology including normal appearances of the cerebrum.

Figure 2 is an example of a normal F-18 FDG PET-CT scan for reference. Normal physiological FDG uptake was seen in the brain (SUV max=12.9, SUV mean=6.5), heart, liver and bowel $(11,12)$.

\section{Literature Review and Discussion}

It is widely believed cerebral perfusion and glucose metabolism may be sustained until all peripheral perfusion is compromised in a dying patient. However, this case unexpectedly demonstrated that cerebral perfusion and glucose metabolism appeared compromised before hepatic and intestinal perfusion and glucose metabolism.

There exist many physiological mechanisms, such as peripheral vascular shutdown in the event of large blood volume loss, to protect central blood circulation (but there is no such vasoconstriction mechanism within the cerebral vascular system itself) (13). But in large, it appears to be a common belief that the cerebral perfusion and glucose metabolism would be the last to be compromised. This myth has been believed and indirectly taught in many medical schools. In this case report, we would like to highlight that this myth may not always be the case.

Diffuse decrease in intracranial glucose metabolism may occur in various conditions (14). Organic diseases such as Alzheimer's dementia and amyloid deposition (15), intracranial infection (16), intracranial atrophy caused by long-standing toxic substances such as alcohol (17), systemic metabolic diseases such as diabetes and resistance to insulin (18) are the common known causes of diffuse decrease in glucose metabolism in the brain. In this case report, the patient did not suffer from any of these diseases and was not on any medications except for an appropriate level of intravenous saline infusion.

A potential learning point of this case report is when significantly reduced cerebral FDG uptake was observed in a PET-CT scan, then staff immediately need to ascertain if the study was conducted appropriately e.g. injection extravasation or wrong dose injection. After exclusion of such operational errors, these abnormal findings should be discussed with duty doctors immediately and appropriate clinical management/resuscitation should be initiated (19).

\section{References}

1. Schmidt GP, Haug A, Reiser MF, Rist C. Whole-body MRI and FDG PET/CT imaging diagnostics in oncology. Radiologe 2010;50:329-338.

2. Okada M, Sato N, Ishii K, Matsumura K, Hosono M, Murakami T. FDG PET/CT versus CT, MR imaging and Ga-67 scintigraphy in the postherapy evaluation of malignant lymphoma. Radiographics 2010;30:939-957 
3. Xing $Y$, Cromwell KD, Cormier JN. Review of diagnostic imaging modalities for the surveillance of melanoma patients. Dermatol Res Pract 2012;2012:941921. Epub 2011 Aug 23.

4. Keller F, Psychogios G, Linke R, Lell M, Kuwert T, Iro H, Zenk J. Carcinoma of unknown primary in the head and neck: Comparison between positron emission tomography (PET) and PET/CT Head Neck 2011 Nov;33:1569-1575. doi: 10.1002/hed.21635. Epub 2010 Dec 15.

5. Dong MJ, Zhao K, Liu ZF, Wang GL, Yang SY, Zhou GJ. A metaanalysis of the value of fluorodeoxyglucose PET/PET-CT in the evaluation of fever of unknown origin. Eur J Radiol 2011;80:834844. Epub 2010 Dec 4.

6. Federici L, Blondet $C$, Imperiale A, Sibilia J, Pasquali JL, Pflumio F, Goichot B, Blaison G, Weber JC, Christmann D, Constantinesco $A$, Andrès $E$. Value of F-18 FDG PET/CT in patients with fever of unknown origin and unexplained prolonged inflammatory syndrome: A single centre analysis experience. Int J Clin Pract 2010;64:55-60. Epub 2008 May 8.

7. Balink H, Collins J, Bruyn GA, Gemmel F. F-18 FDG PET/CT in the diagnosis of fever of unknown origin. Clin Nucl Med 2009 34:862-868.

8. Bleeker-Rovers CP, van der Meer JWM, Oyen WJG. Fever of unknown origin. Seminars in Nuclear Medicine. 2009;39:81-87.

9. Adams MC, Turkington TG, Wilson JM, Wong TZ. A systematic review of the factors affecting accuracy of suv measurements. AJR Am J Roentgenol 2010;195:310-320.

10. Liu Y, Ghesani NV, Zuckier LS. Physiology and pathophysiology of incidental findings detected on FDG PET scintigraphy. Semin Nucl Med 2010;40:294-315.

11. Gorospe L, Raman S, Echeveste J, Avril N, Herrero Y, Herna Ndez S. Whole-body PET/CT: Spectrum of physiological variants, artifacts and interpretative pitfalls in cancer patients. Nucl Med Commun 2005;26:671-687.
12. Townsend DW. Positron emission tomography/computed tomography. Semin Nucl Med 2008;38:152-166.

13. Rhoades RA. Medical physiology: Principles for clinical medicine. 3 ed. 2008: Wolters Kluwer. 294-295.

14. Herholz K. Perfusion spect and SPECT and FDG PET. Int Psychogeriatr 2011;23 Suppl 2:S25-31.

15. Kikuchi M, Hirosawa T, Yokokura M, Yagi S, Mori N, Yoshikawa E, Yoshihara Y, Sugihara G, Takebayashi K, Iwata Y, Suzuki K, Nakamura K, Ueki T, Minabe Y, Ouchi Y. Effects of brain amyloid deposition and reduced glucose metabolism on the default mode of brain function in normal aging. J Neurosci 2011;31:11193-11199.

16. Heeren $M$, Weissenborn $K$, Arvanitis $D$, Bokemeyer $M$, Goldbecker $A$, Tountopoulou A, Peschel T, Grosskreutz J, Hecker H, Buchert R, Berding G. Cerebral glucose utilisation in Hepatitis $C$ virus infectionassociated encephalopathy. J Cereb Blood Flow Metab 2011;31:2199-2208. doi: 10.1038/jcbfm.2011.82. Epub 2011 Jun 1.

17. Volkow ND, Wang GJ, Franceschi D, Fowler JS, Thanos PP, Maynard L, Gatley SJ, Wong C, Veech RL, Kunos G, Kai Li T. Low doses of alcohol substantially decrease glucose metabolism in the human brain. Neuroimage 2006;29:295-301.

18. Bosco D, Fava A, Plastino M, Montalcini T, Pujia A. Possible implications of insulin resistance and glucose metabolism in alzheimer's disease pathogenesis. J Cell Mol Med 2011;15:18071821. doi: 10.1111/j.1582-4934.2011.01318.x.

19. Pagano L, Samà MT, Morani F, Prodam F, Rudoni M, Boldorini R, Valente G, Marzullo P, Baldelli R, Appetecchia M, Isidoro C, Aimaretti G. Thyroid incidentaloma identified by (18)Ffluorodeoxyglucose positron emission tomography with CT/FDG PET/CT: Clinical and pathological relevance. Clin Endocrinol (Oxf) 2011;75:528-534 